\title{
Relationship Between Spiritual Well-Being and Quality of Life Among Students in Southeast-Asia Countries
}

\author{
Pamela Hendra Heng ${ }^{1 *}$ Franklin Hutabarat ${ }^{2}$ Septi Lathiifah ${ }^{1}$
}

\author{
${ }^{1}$ Faculty of Psychology, Universitas Tarumanagara, Jakarta Barat, 11440, Indonesia \\ ${ }^{2}$ Faculty of Religious Studies, Asia-Pacific International University, Thailand, Muak Lek, Saraburi 18180, Thailand \\ *Corresponding author. Email: pamelah@fpsi.untar.ac.id
}

\begin{abstract}
Suspending classes for university students as well as suspending worship services either at university or at public places to combat the Covid-19 disease may affect the spiritual well-being and quality of life of students in Southeast-Asia countries. This research aimed at evaluating quality of life and spiritual well-being among students of the Asia-Pacific International Universities in Muak Lek, Thailand and in Jakarta, Indonesia. The method is a non-experimental quantitative correlational research. The participants consist of 52 students from Thailand and 54 students from Indonesia. For this purpose, questionnaires were prepared and surveys of the two universities were conducted to gather quantitative data. The Spiritual Well-Being Questionnaire (SWQ) constructed by Gomez \& Fisher [1] which consists of 20 questions based on Fisher [2] theory of four spiritual dimensions of well-being, namely personal, communal/universal, environmental, and transcendental domains were being used to measure the spiritual well-being of the participants. While the WHOQOL-BREF instrument adapted by Purba et. al. [3] which consists of 26 questions that have four dimensions, namely the physical, psychological, social relations and social environment were being used to measure the quality of life of the participants.
\end{abstract}

Keywords: Spiritual well-being, quality of life, Student

\section{INTRODUCTION}

The World Health Organization (WHO), in January 2020, declared the COVID-19 pandemic a world public health emergency [4]. Indonesia and Thailand are two of the many governments in the world that have decided to temporarily provide various public facilities including suspending classes for university students and suspending worship at public places of worship to combat the COVID19 disease. This fact reduces the quality of spiritual wellbeing and social welfare. Social distancing, quarantine and isolation are solutions provided to slow the spread of COVID-19 disease in the community. This solution suddenly changed people's lives in general. Unless there is a task that is necessary, the majority of people will stay at home, so they feel deprived of freedom and stay at home longer than usual. This results in decreased happiness and increased stress [5]. Thailand has the fifth confirmed COVID-19 cases in Southeast Asia, after Singapore, Malaysia, the Philippines and Indonesia [4]. The Thai government implemented it, starting from March 26 to April 30, to slow the spread of the COVID-19 [6]. The government banned large gatherings, and places with a high risk of infection were closed. Classes are suspended; places of worship temporarily closed and meet online. Students experience activities at home longer than usual. Immobility reduces physical activity and can lead to decreased physical health and spiritual well-being [7].
While in Indonesia, various incidents that show psychological and spiritual well-being can be found in various media. Cases such as bullying, premeditated murder of elementary school students, beatings by seniors, suicides and attempted suicide [8]. Another example that shows an alarming development is the development of the abuse of narcotics, psychotropic and other addictive substances (NAFZA). In 2006, recorded total drug users in Indonesia reached 3.2 million people. As many as 1.1 milion of them are users from elementary, junior high, high school and college students. Approximately $0.72 \%$ or 8,000 elementary school students in Indonesia were found to be drug users in that year [9].

The behaviour of students becomes violent and destructive. This is in stark contrast with the hopes and goals of Indonesia's national education as stipulated in Law No. 20 of 2003 concerning the National Education System (Chapter II Article 3). It says National education functions to develop abilities and shape character and a dignified national civilization in the context of the intellectual life of the nation, aims to develop the potential of students to become human beings who believe and fear God Almighty, have noble character, are healthy, knowledgeable, capable, creative, independent, and become democratic and responsible [10]. Noble morals which are based on faith and devotion are the main goals of education, but the reality on the ground shows the 
opposite facts, anarchic behaviour and immoral actions are increasingly common and become common habits in everyday life that show the dry and unsustainable psychological and spiritual condition of students. The worrisome conditions that continue to emerge provide signals for changes and improvements in current educational practices.

There are four dimensions of human health, namely, somatic, social, psychological and spiritual well-being. In particular, spiritual well-being has positive effects such as improving general health and addressing other aspects of health that will promote compatibility and functionality of psychological well-being [11]. It is also related to aspects such as peace of mind, stability in life, a sense of having a better relationship with oneself, society, environment and God, as well as balance and harmony of life goals [12]. Religion and spirituality are considered as very important elements in dealing with the pressures of life [13]. If spiritual well-being is not attained, then other dimensions such as biological, psychological and social human health cannot function properly or reach maximum capacity. Therefore, the highest quality of life cannot be attained [14]. Spiritual well-being is an important factor that is closely related to those affecting the quality of life [11].

Spiritual well-being is the quality of the relationship a person has with himself, others, nature, and God [2, 11]. These are the four domains of spiritual well-being according to Fisher: (1) personal domain, an interrelation of a person related to the meaning, purpose and value of life. (2) the communal/universal domain, namely the quality of the relationship between oneself and others, its relation to morality, culture and religion which is shown through loving attitudes, forgiveness, belief, hope and belief in humanity. (3) the environmental domain, namely an attitude that is more than physical and biological care and maintenance, therefore there is a feeling of awe and wonder so that it can blend with the environment. (4) the transcendental domain, namely the relationship between oneself and something beyond the human level (such as the most Noble, cosmic power, transcendental reality or God), including belief, worship or worship of God [15].

The key role in public health and personal and social life is closely related to the assessment of the quality of life and progress [16]. Well-being and life satisfaction are two things in consideration of a person's mental perception of quality of life [17]. Piraste Motlagh et al. [18] stated that there is a significant positive relationship between quality of life and spirituality. Osarrodi et al. [19] then proves that between the different dimensions of quality of life and higher levels of spiritual well-being there is a significant relationship. Jadidi et al. suggested that there is a significant relationship between the quality of life of the elderly and spiritual well-being [20]. Research conducted by Alahbakhshian et al. shows that between the religious aspects of spiritual welfare and quality of life, in the mental dimension there is a significant relationship [21]. The comfort of human life is one of the things that affect religious beliefs, and can strengthen the main dimensions of the individual and society, fill emotional, moral and spiritual gaps and provide peace of mind. Religious beliefs also provide a solid foundation in dealing with the shortcomings and difficulties of life. Almighty God always supports and provides assurance to people who make spiritual connections with universal powers. By relying on the beliefs they have, these people face complexity more easily and are less bothered by the stress and difficulties that may come in the future, and they are more optimistic and have high expectations [20]. Baljani et. al. in his study showed that between spiritual well-being and hope and the order of quality-of-life performance there is a significant positive relationship. And overall between quality of life and spiritual well-being has a significant relationship [22]. They also emphasize that between religious belief and spiritual well-being and between spiritual well-being and optimism on a significant relationship [22]. Decreased quality of life can occur due to all factors that negatively affect the feeling of both the ability and feelings of individuals in carrying out daily activities [23]

\section{PURPOSE OF THE STUDY}

Based on the information above, the purpose of this study is to determine the relationship between spiritual wellbeing and quality of life among students in Southeast-Asia countries.

\section{METHODS}

This research approach is quantitative in non-experimental terms and uses a questionnaire to collect data. The assessment instruments being used to measure the spiritual well-being of the participants is the Spiritual Well-Being questionnaire (SWQ) constructed by Gomez \& Fisher [1] which consists of 20 questions based on Fisher [2] theory of four spiritual dimensions of well-being, namely personal, universal, environmental, and transcendental domains. Meanwhile, the WHOQOL-BREF instrument adapted by Purba et. al [3] which consists of 26 questions is being used to measure the quality of life of the participants in general and four dimensions, namely the physical, psychological, social relations and social environment. In 2021, this study was conducted among 52 Southeast Asia-Pacific International University X students in Muak Lek, Thailand, and 54 Universitas Y students in Jakarta, Indonesia. 47 were male participants and 59 were female participants. Participants who are 18 years of age are 3, participants who are 19 years of age are 10 , participants who are 20 years of age are 48, participants who are 21 years of age are 15 , participants who are 22 years of age are 11, and participants who are > 22 years of age are 19.

There were 100 participants who are in the Bachelor's program, 1 Master's program participant, and 5 participants from the other educational program. There were 53 people participating from the psychology course, 21 people participating from the theology course, 7 people participating from science course, 5 people participating from the English course, 4 people participating from the IT course, and 16 people participating from the other course. 
Christian participants are 67 individuals, Catholic participants are 13 individuals, Muslim participants are 14 individuals, Buddhist participants are 7 individuals, Hindu participant is 1 individual, non-religious participants are 2 individuals, and other religious participants are 2 individuals.

\section{FINDINGS AND DISCUSSIONS}

\subsection{Description of Spiritual Well-Being Data}

The data for spiritual well-being using a Likert scale of 1-5 has a hypothetical mean of measuring instrument, namely 3 , while the empirical mean is 3.7915 . The empirical mean score obtained has a higher value than the hypothetical mean score, thus the participants' spiritual well-being is in the high category.

\subsection{Description of Quality of Life Data}

The data description for quality of life using a Likert scale of 1-5 has a hypothetical mean of the measuring instrument, which is 3 , while the empirical mean is 3.6839 . The empirical mean score obtained has a higher value than the hypothetical mean score, thus the participants' quality of life is in the high category.

Quality of life in general data description has a hypothetical mean of 3 while the empirical mean score is 3.7406. The empirical mean score was higher than the hypothetical mean score, thus the quality of life domain 1 participant was classified as high. Domain 1 data description has a hypothetical mean of 3 while the empirical mean score is 3.7264 . The empirical mean score was higher than the hypothetical mean score, thus the quality of life domain 1 participant was classified as high. For domain 2, it has a hypothetical mean of 3 while the empirical mean is 3.6340 . The empirical mean score was higher than the hypothetical mean score, thus the quality of life domain for the 2 participants was high. In domain 3 , it has a hypothetical mean of 3 while the empirical mean is 3.6572. The empirical mean score was higher than the hypothetical mean score, thus the quality of life domain for the 3 participants was high. Then, the last domain 4 has the hypothetical mean of 3 while the empirical mean is 3.6616. The empirical mean score was higher than the hypothetical mean score, thus the quality of life domain for 4 participants was high.

\subsection{Relationship Spiritual Well-Being and Quality of Life}

From the data analysis using the Pearson correlation with normally distributed data, the results obtained were $\mathrm{R}=$ $0.468, \mathrm{p}=0.000<0.05$, which means that there is a significant positive relationship between spiritual wellbeing and quality of life. Which can be concluded that the higher spiritual well-being, the higher the quality of life.
Otherwise, the lower spiritual well-being, the lower the quality of life.

Table 1 Relationship spiritual well-being and quality of life

\begin{tabular}{ccc}
\hline & $\mathrm{R}$ & $\mathrm{P}$ \\
\hline $\begin{array}{c}\text { Correlation Spiritual } \\
\text { Well-Being and Quality } \\
\text { of Life }\end{array}$ & 0.468 & 0.000 \\
\hline
\end{tabular}

\subsection{Different Tests of Spiritual Well-Being based on Gender}

In Levene's test for equality of variances, it appears that the value of $F=2.266$ and $p=0.135(p>0.05)$. Therefore, the difference test will refer to the equal variances assumed. Independent sample t-test was conducted to test the $\mathrm{F}$ value in order to determine the similarities or differences in variance between male and female participants. The results are based on $\mathrm{p}$ from the $\mathrm{F}$ value greater than .05 , then $\mathrm{t}=0.777$ and $\mathrm{p}=0.439 ; \mathrm{p}>0.05$. This shows that there is no difference in spiritual wellbeing based on gender.

Table 2 Different tests of spiritual well-being based on gender

\begin{tabular}{lcccc}
\hline & $\mathrm{F}$ & $\mathrm{P}$ & $\mathrm{t}$ & $\mathrm{p}$ \\
\hline $\begin{array}{l}\text { Spiritual } \\
\text { Well- }\end{array}$ & 2.266 & 0.135 & 0.777 & 0.439 \\
Being & & & & \\
\hline
\end{tabular}

\subsection{Different Tests Spiritual Well-Being based on Age}

Based on the One-Way ANOVA analysis, it is known that $\mathrm{F}=2.819, \mathrm{p}=0.020<0.05$ indicates that there are differences in the spiritual well-being of participants based on age.

Table 3 Different tests spiritual well-being based on age

\begin{tabular}{ccc}
\hline & $\mathrm{F}$ & $\mathrm{P}$ \\
\hline $\begin{array}{c}\text { Spiritual Well- } \\
\text { Being }\end{array}$ & 2.819 & 0.020 \\
\hline
\end{tabular}

\subsection{Different Tests of Spiritual Well-Being based on Location}

In Levene's test for equality of variances, it appears that the value of $F=4.159$ and $p=0.044(p<0.05)$. This shows that there are differences in spiritual well-being based on location. 
Table 4 Different tests of spiritual well-being based on location

\begin{tabular}{lcccc}
\hline & $\mathrm{F}$ & $\mathrm{P}$ & $\mathrm{t}$ & $\mathrm{P}$ \\
\hline $\begin{array}{c}\text { Spiritual } \\
\text { Well- }\end{array}$ & 4.159 & 0.044 & -2.146 & 0.034 \\
Being & & & & \\
\hline
\end{tabular}

\subsection{Different Test of Spiritual Well-Being based on Education}

Based on the One-Way ANOVA analysis, it is known that $\mathrm{F}=0.620, \mathrm{p}=0.540>0.05$ indicates that there is no difference in the spiritual well-being of the participants based on education.

Table 5 Different test of spiritual well-being based on education

\begin{tabular}{ccc}
\hline & $\mathrm{F}$ & $\mathrm{P}$ \\
\hline $\begin{array}{c}\text { Spiritual Well- } \\
\text { Being }\end{array}$ & 0.620 & 0.540 \\
\hline
\end{tabular}

\subsection{Different Tests of Spiritual Well-Being based on Course}

Based on the One-Way ANOVA analysis, it is known that $\mathrm{F}=3.361, \mathrm{p}=0.008<0.05$ indicates that there are differences in the spiritual well-being of the participants based on the major.

Table 6 Different tests of spiritual well-being based on course

\begin{tabular}{ccc}
\hline & $\mathrm{F}$ & $\mathrm{P}$ \\
\hline $\begin{array}{c}\text { Spiritual Well- } \\
\text { Being }\end{array}$ & 3.361 & 0.008 \\
\hline
\end{tabular}

\subsection{Different Tests of Spiritual Well-Being based on Religion}

Based on the One-Way ANOVA analysis, it is known that $\mathrm{F}=1.099, \mathrm{p}=0.369>0.05$ indicates that there is no difference in the spiritual well-being of the participants based on religion.

Table 7 Different tests of spiritual well-being based on religion

\begin{tabular}{ccc}
\hline & $\mathrm{F}$ & $\mathrm{P}$ \\
\hline $\begin{array}{c}\text { Spiritual Well- } \\
\text { Being }\end{array}$ & 1.099 & 0.369 \\
\hline
\end{tabular}

\subsection{Different Test of Quality of Life based on Gender}

In Levene's test for equality of variances, it appears that the value of $F=0.874$ and $p=0.352$ ( $p>0.05)$. Therefore, the difference test will refer to the equal variances assumed. Independent sample t-test was conducted to test the $\mathrm{F}$ value in order to determine the similarities or differences in variance between male and female participants. The results are based on $\mathrm{p}$ from the $\mathrm{F}$ value that is greater than .05 , then $t=-0.570$ and $p=0.570 ; p>$ 0.05 . This shows that there is no difference in quality of life based on gender.

Table 8 Different test of quality of life based on gender

\begin{tabular}{lcccc}
\hline & $\mathrm{F}$ & $\mathrm{P}$ & $\mathrm{T}$ & $\mathrm{p}$ \\
\hline $\begin{array}{l}\text { Quality } \\
\text { of Life }\end{array}$ & 0.874 & 0.352 & -0.570 & 0.570 \\
\hline
\end{tabular}

\subsection{Different Test of Quality of Life based on Age}

Based on the One-Way ANOVA analysis, it is known that $\mathrm{F}=3.963, \mathrm{p}=0.003<0.05$ indicates that there is a difference in the quality of life of the participants based on age.

Table 9 Different test of quality of life based on age

\begin{tabular}{ccc}
\hline & $\mathrm{F}$ & $\mathrm{P}$ \\
\hline Quality of Life & 3.963 & 0.003 \\
\hline
\end{tabular}

\subsection{Different Test of Quality of Life based on Location}

In Levene's test for equality of variances, it appears that the value of $F=0.529$ and $p=0.469(p>0.05)$. Therefore, the difference test will refer to the equal variances assumed. The independent sample t-test was conducted to test the $F$ value to determine the similarities or differences in variance between participants located in Indonesia and Thailand. The results are based on $\mathrm{p}$ from an $\mathrm{F}$ value that is greater than .05 , then $t=0.878$ and $p=0.382 ; p>0.05$. This indicates that there is no difference in quality of life based on the location of the participants.

Table 10 Different test of quality of life based on location

\begin{tabular}{ccccc}
\hline & $\mathrm{F}$ & $\mathrm{P}$ & $\mathrm{T}$ & $\mathrm{P}$ \\
\hline $\begin{array}{c}\text { Quality } \\
\text { of Life }\end{array}$ & 0.529 & 0.469 & 0.878 & 0.382
\end{tabular}

\subsection{Different Test of Quality of Life based on Education}

Based on the One-Way ANOVA analysis, it is known that $\mathrm{F}=1.324, \mathrm{p}=0.270>0.05$ indicates that there is no difference in the quality of life of the participants based on education. 
Table 11 Different test of quality of life based on education

\begin{tabular}{ccc}
\hline & $\mathrm{F}$ & $\mathrm{P}$ \\
\hline Quality of Life & 1.324 & 0.270 \\
\hline
\end{tabular}

\subsection{Different Test of Quality of Life based on Course}

Based on the One-Way ANOVA analysis, it is known that $\mathrm{F}=4.059, \mathrm{p}=0.002<0.05$ indicates that there is a difference in the quality of life of the participants based on the major. Complete data on quality of life by majors.

Table 12 Different test of quality of life based on course

\begin{tabular}{ccc}
\hline & $\mathrm{F}$ & $\mathrm{P}$ \\
\hline Quality of Life & 4.270 & 0.002 \\
\hline
\end{tabular}

\subsection{Different Test of Quality of Life based on Religion}

Based on the One-Way ANOVA analysis, it is known that $\mathrm{F}=0.427, \mathrm{p}=0.860>0.05$ indicates that there is no difference in the quality of life of the participants based on religion. Complete data on quality of life based on religion.

Table 13 Different test of quality of life based on religion

\begin{tabular}{lcc}
\hline & $\mathrm{F}$ & $\mathrm{P}$ \\
\hline Quality of Life & 0.427 & 0.860 \\
\hline
\end{tabular}

\section{CONCLUSIONS}

Based on the data, it is known that there is a significant positive relationship between spiritual well-being and quality of life. This means that the higher the spiritual well-being, the higher the quality of life, and otherwise, the lower the spiritual well-being, the lower the quality of life. Researchers also performed different tests on the variables of spiritual well-being and quality of life. In the results of the spiritual well-being difference test, it is known that there are differences in spiritual well-being when viewed based on age, location and course. Meanwhile, in the results of the quality of life difference test, it shows that there are differences in the quality of life in terms of age and course.

\section{ACKNOWLEDGMENT}

This work was funded and supported by Institute of Research \& Community Engagement, the manager of research department and the Dean of Faculty of Psychology, UNTAR; and the
Associate Dean of Faculty of Psychology, UNTAR. The researchers are grateful for this opportunity to have a Southeast Asia collaboration research.

\section{REFERENCES}

[1] R. Gomez, and J. Fisher, "Domain of spiritual wellbeing and development and validation of the spiritual well-being questionnaire," Personality and Individual Differences, 2003, doi: 10.1016/S0191-8869(03)00045$\mathrm{X}$

[2] J. Fisher, "Comparing levels of spiritual well-being in state, Catholic and independent schools in Victoria, Australia," Journal of Beliefs and Values, 2001

[3] F.D. Purba, J.A.M. Hunfeld, A. Iskandarsyah, T.S Fitriana, S.S. Sadarjoen, J. Passchier, J.V. Busschbach, "Quality of life of the Indonesian general population: Testretest reliability and population norms of the EQ5D-5L and WHOQOL-BREF," PLoS ONE 13(5), 2018, e0197098. Doi: https://doi.org/10.1371/journal.pone. 0197098

[4] World Health Organization, "Mental Health and Psychosocial Considerations During COVID-19 Outbreak," World Heal. Organ., 2020.

[5] S. Bhandari et al., "The sequel to COVID-19: the antithesis to life," J. Ideas Heal., 2020, doi: 10.47108/jidhealth.vol3.issspecial1.69.

[6] C. Del Rio and P. N. Malani, "COVID-19 - New Insights on a Rapidly Changing Epidemic," JAMA Journal of the American Medical Association. 2020, doi: 10.1001/jama.2020.3072.

[7] H. Dong, J. Zhang, and C. Cirillo, "Exploring, understanding, and modeling the reciprocal relation between leisure and subjective well-being," Transp. Res. Part A Policy Pract., 2019, doi: 10.1016/j.tra. 2019.10.009.

[8] Y. Febriyani and E. Indrawati, " Konformitas teman sebaya dan perilaku bullying pada siswa kelas XI IPS," Empati, 2016.

[9] R. N. Fitri, "Pengaruh Pembentukan Karakter dengan Kecerdasan Spiritual di SMA Negeri 22 Palembang," J. Intelekt. Keislaman, Sos. dan Sains, 2016.

[10] S. N. R. Indonesia and Bambang, "UndangUndang tentang Sistem Pendidikan Nasional. BAB," 
Lembaran Negara Republik Indones. Nomor 4301), 2003.

[11] J. Fisher, "The four domains model: Connecting spirituality, health and well-being," Religions, 2011, doi: $10.3390 /$ rel2010017.

[12] E. Jafari, G. R. Dehshiri, H. Eskandari, M. Najafi, R. Heshmati, and J. Hoseinifar, "Spiritual well-being and mental health in university students," 2010, doi: 10.1016/j.sbspro.2010.07.311.

[13] K. S. Seybold and P. C. Hill, "The role of religion and spirituality in mental and physical health," Curr. Dir. Psychol. Sci., 2001, doi: 10.1111/14678721.00106 .

[14] C. W. Ellison, "Spiritual Well-Being: Conceptualization and Measurement," J. Psychol. Theol., 1983, doi: 10.1177/009164718301100406.

[15] J. Fisher, "Development and application of a spiritual well-being questionnaire called SHALOM," Religions, 2010, doi: 10.3390/rel1010105.

[16] M. Jolly, W. Sequeira, and J. A. Block, "Health and quality of life outcomes," Health and Quality of Life Outcomes. 2014, doi: 10.1186/s12955-014-0173-5.

[17] M. F. A. \& K. U, "Quality of lfie of patients with ESRF_REad,” Contrib Nephrol. Basel Karger, 1991.

[18] A. A. Pirasteh Motlagh, Z. Nikmanesh, E. Liaghat, and M. Hematian, " The role of religion and spirituality in mental and physical health," Current Directions in Psychological Science, 2019, doi: https://doi.org/10.29252/jrh.9.2.104

[19] A. Osarrodi, A. Golafshani, and S. Akaberi, "Relationship between spiritual well-being and quality of life in nurses," J. North Khorasan Univ. Med. Sci., 2012, doi: 10.29252/jnkums.3.4.79.

[20] J. Ali, F. Marhemat, J. Sara, and H. Hamid, "The Relationship between Spiritual Well-Being and Quality of Life among Elderly People," Holist. Nurs. Pract., 2015, doi: 10.1097/HNP.0000000000000081.

[21] M. Allahbakhshian, M. Jaffarpour, S. Parvizy, and H. Haghani, "A Survey on relationship between spiritual wellbeing and quality of life in multiple sclerosis patients," ZAHEDAN J. Res. Med. Sci., 2010.

[22] E. Baljani, M. Kazemi, E. Amanpur, and T. Tizfahm, "The Relationship between Religion, Spiritual Well-being, Hope and Quality of Life in Patients with Cancer," Faslname Daneshkade Parastar Va Mamayee
Mashhad, 2011.

[23] P. Theofilou, "Quality of life: Definition and measurement," Eur. J. Psychol., 2013, doi: 10.5964/ ejop.v9i1.337. 